\title{
The continued adoption of housing systems in the Netherlands: A multiple case study
}

\author{
J.A.W.H. van Oorschot ${ }^{1}$ iD, J.I.M. Halman*1 iD, E. Hofman ${ }^{2}$ iD \\ ${ }^{1}$ University of Twente, School of Engineering Technology, Department of Civil Engineering, Enschede, \\ The Netherlands \\ ${ }^{2}$ University of Twente, School of Behavioural, Management and Social Sciences, Department of \\ Technology Management and Supply, Enschede, The Netherlands
}

\begin{abstract}
Extensive governmental and industry efforts have been devoted to developing innovative housebuilding systems. However, it appears a challenge for housebuilding firms to move beyond their demonstration status and get their housing system adopted at a large scale and over a longer period. This is problematic since worsening developments concerning the environmental impact, poor production efficiency and a lack of client orientation of traditional building practices remain unsolved. This article describes a multiple case study on the continued adoption of innovative industrial housing systems. The multiple case study centers around a housing system which is generally considered as a rare example of an industrial housing system that has succeeded in the last 30 years in maintaining a leading position in the Dutch housing sector. This article analyses the reasons for this continued adoption in contrast to three industrial housing systems which had to abandon the market. The case study findings show that at least five mechanisms play a decisive role in the eventual continued adoption: the regional presence of the builder; the builders' operational excellence; a natural fit with existing technology standards; a competitive added value, and; the ability of the housebuilder to keep pace with changing market requirements. An important lesson from this study is that, for continued adoption, one needs to stay alert and adapt the housing system to changing market requirements.
\end{abstract}

\section{Keywords}

Innovation; Continued adoption, Industrial housing, Residential sector

Received: 04 August 2019; Accepted: 12 December 2019

ISSN: 2630-5771 (online) (C) 2019 Golden Light Publishing All rights reserved.

\section{Introduction}

In recent decades, extensive governmental and industry efforts have focused on developing and constructing sustainable, industrialized and customer oriented solutions for the housing market [1-4]. Despite several efforts, it appears a challenge for house building firms to move beyond their demonstration status $[5,6]$ and get their housing

\footnotetext{
* Corresponding author

Email: j.i.m.halman@utwente.nl
}

system adopted at a large scale and over a longer period.

Nevertheless, exceptions do exist, as is the case with the W\&R Housing system pertaining to the Royal BAM Group in the Netherlands. W\&R, a Dutch abbreviation, expresses two core values of the housing system: it provides high quality and spacious housing units. This housing system combines an efficient on-site method to construct 
the load-bearing system with a growing number of add-on prefabricated elements as a result of increased prefabrication and variation. This system was firstly introduced in 1992 in the Dutch housing market. Since its introduction in 1992, almost 20,000 housing units were delivered so far. This raises the question why the $\mathrm{W} \& \mathrm{R}$ housing system succeeded to keep its strong market position in the Netherlands for such a relative long period while many other attractive housing systems did not survive.

Although a literature search revealed a substantial body of literature about housing innovation adoption, informative literature about continued adoption over a longer period in time and across various housing projects appeared to be very limited. An understanding of the factors affecting the continued adoption of a housing system is nevertheless essential for scholars studying the determinants of continued adoption as well as for the creators and producers of such housing systems. Also knowledge about the reasons behind a discontinued adoption can be considered as crucial since industrial housing systems are found key to address several worsening developments in the housing sector, in particular regarding a growing housing shortage [7-9]. This article therefore attempts to contribute in closing this gap in literature by answering the following two research questions:

1) What differentiates the $W \& R$ housing system from housing systems, which did not experience a continued adoption?

2) Which mechanisms contribute to a continued adoption over time and across housing projects?

The overall aim of this research has been to unravel the mechanisms which shape the potential continued adoption of industrial housing systems in the Dutch housing sector. The research questions have been addressed by conducting a longitudinal case study of the W\&R housing system and a robustness check by comparison of the findings with three less successful industrial housing systems. To our knowledge, this is the first study that encompasses a longitudinal case study about the adoption of a successful industrial housing system which has been continuously adopted across various projects over time, relative to three competitive housing systems which abandoned the market.

The rest of this article is structured as follows. Based on a literature review, we define in section 2 the concept of a housing system and explain why it is important that innovative and industrial housing systems are adopted at a large scale across projects. In section 2 also the literature about 'continued adoption' will be discussed. In the third section, we provide details about the different research steps that we followed when conducting this study. In the fourth section, the research findings are presented including the successive phases in the lifecycle of the W\&R housing system and the stage-gated adoption process when selecting housing systems. In the fifth section, a comparison is made between the W\&R housing system and three other housing systems that did not survive in the market after an initial successful adoption. Based on the case study material, this section also deduces a number of critical mechanisms that secure a continued adoption of housing systems. Finally, the last section discusses the scientific and managerial contributions and possible directions for future research.

\section{Literature review}

Industrial (house)building (IB) aims at raising efficiency by rationalising the construction process through the adoption of production technologies and methods found in highly industrialized massproduction industries like automotive. In the past decades various IB methods have been developed. These IB methods are often addressed as 'modern methods of construction'. They range from industrialized on-site construction methods to the off-site production of volumetric pods [10-14]. The three underpinning characteristics portraying the essence of IB are standardisation; prefabrication, and; system building [15]. Standardization is considered a prerequisite for the application of industrial production processes, both on- and offsite $[3,16]$. The predominant application of industrialised production methods is usually off- 
site prefabrication [3, 17]. However, industrialized house building could also include site-based methods while still applying industrialised design and production principles [18]. The term 'systems building' has been introduced to describe a set of building components which are linked together and that require a well-coordinated system of technical and organizational interfaces $[3,19,20]$. Based on these general characteristics an industrial housing system (IHS) can be defined as: the application of mass-production principles to construct housing. Industrial housing systems involve on- and off-site production methodologies within a controlled environment, and delivered through a wellcoordinated integrated system [21-24].

Despite the reported benefits, many industrial housing systems are hardly applied beyond their demonstration status across a range of subsequent projects, i.e. 'the history of IB is rich in examples of failures' $[25,26]$. This discontinued adoption is problematic, since the housing market, clients and industry alike, do not benefit from the potential of industrial building practices [21, 27-31]. It may be considered as a missed opportunity, since industrial housing systems have been identified as an important condition for solving worsening developments in the housing sector such as labour and skills shortage [8]; significant housing shortage [9] and a detrimental environmental impact [7].

Many innovations seem to fall into a chasm after they have been adopted by early adopters in the market [32-34] and subsequently fail to be adopted beyond demonstration projects [5, 6, 35]. In particular in the construction and housing sector, demonstration projects are considered a key vehicle to innovation and change, while they create environments for $\mathrm{R} \& \mathrm{D}$ and learning [35-39]. Despite to the importance of demonstration projects with respect to innovation in the construction and housing sector, only few explorative studies, which tend to focus on sustainable building, have been conducted to research the adoption and implementation of innovation in demonstration projects and beyond [5, 6, 40].

Regarding the adoption of sustainable innovation, Van Hal [5] identified four interrelated variables affecting adoption beyond demonstration: 1) quality of the innovation; 2) organization of the demonstration project; 3) organization of the information transfer, and; 4) influence of the government. First, a demonstration project only contributes to subsequent adoption if it proofs that the innovation is of sufficient quality and has commercial potential. Second, also the project organization is key to subsequent adoption. It has been found that inter-disciplinary cooperation and the involvement of an innovation champion are increasing the chance of further adoption. Third, the absence of a properly organized information transfer has been identified as a key barrier to adoption in subsequent projects. Research results showed that information transfer must centre around unambiguous and uniform evaluations and must target different stakeholder groups in the industry. The importance of a change agency (public authority), responsible for knowledge dissemination across the industry has also been emphasized. Fourth, Van Hal showed that the government, as a regulator, initiator, stimulator and change agency, could substantially impact the change of adoption beyond demonstration.

Research conducted by Femenias [6] reveals that the poor effect of demonstration projects to the wider uptake of innovation can be attributed to: 1) lack of incentives and interest to learn from experience; 2) lack of compilation and dissemination of reliable and useful findings; 3) a gap between the ideals of the demo projects and the ideals of involved stakeholders, and; 4) the perception that demo projects are considered as being special projects and side-tracks from mainstream building.

Despite the above noted valuable insights about a continued adoption of an industrial housing system beyond its demonstration phase, some important research lacuna's can be identified. First of all, the uptake of innovations like industrial housing systems are found to be intrinsically linked to project procurement [41, 42]. Current research did not yet bridge the gap between project procurement and innovation adoption theory [4244]. Second, longitudinal case studies focusing on 
the adoption of innovation across projects over time are scarce. In particular studies which study the extend adoption determinants that change over time are limited [45, 46]. Third, there is a lack of empirical data about why some innovations fail to be adopted across projects relative to successful competitive alternatives as can be found in the field of industrial housing systems. This research aims to close these gaps by conducting a multiple casestudy.

\section{Research method}

\subsection{Research method and sample}

An in-depth case study aims at providing insight into a phenomenon of interest and contributes to theory building. A multiple case study extends an in-depth case study to examine multiple cases where the focus is both within and across cases [47], and as a result can deepen the understanding of the phenomena [48]. A multiple case-study also provides the ability to generalize findings to a broader range of situations through appropriate case selection and cross-case comparison [47-50]. Therefore, this multiple case study encompasses four industrial housing systems. The four case studies share a specific feature: they all apply alternative but proven industrial building methods in contrast to traditional housebuilding. The four cases have in common that they apply a standardized housing design and/or a standardized housebuilding process in order to make industrialization and the application of modern construction methods possible. These industrial building methods include both on- and off-site technologies, but in all four cases off-site produced, prefabricated building components are used. Yet the four case studies most differ from each other with respect to our research interest: continued adoption. Of these four housing systems only one, the W\&R housing system (further referred to as "W\&R"), has experienced a continued adoption over a long period of time. Therefore $\mathrm{W} \& \mathrm{R}$ was selected to be studied longitudinally. W\&R was developed by the Royal BAM group (further referred to as "BAM"). BAM is the largest contractor in the Dutch construction sector. Since the initial development of W\&R in 1990 and the first delivery in 1992, several upgrades, in terms of both product and process improvements have been realized. These improvements were largely motivated by changing market conditions. With over 20,000 W\&R dwellings erected since 1992, W\&R became a market leader in The Netherlands in the supply of newly constructed houses. In addition to the $\mathrm{W} \& \mathrm{R}$ case and as a robustness check of our findings (cfm. George and Bennet [50] and Gerring [51]), we compared W\&R with three less successful industrial housing systems: the Concrete Slab housing system; the Wooden Frame housing system and the Steel Frame housing system (The names of the housing systems have been altered and reflect the core design of the industrialized housing system). These three cases were selected from a larger pool of industrial housing systems which abandoned the market applying the following inclusion criteria: a) the housing systems were applied in the same housing market segment; b) they had relatively recently abandoned the market and; c) key stakeholders involved with the housing system could be identified and were willing to participate in the case study.

\subsection{Data collection and analysis}

The data collection and analysis for this study was conducted in six phases. The aim of the first phase was to gain an understanding of the process of adoption and diffusion of innovations in general, and more specifically, of the development and implementation of industrialized housing systems. Consequently, the relevant adoption and diffusion literature was reviewed. From this we learned that continued adoption, i.e. the adoption of housing innovation in various projects over time, has hardly been selected as a topic for further analysis. During the first stage of this study, also 15 exploratory interviews with various actors in the housing market, such as social housing associations, project developers, architects, contractors, municipalities and researchers, were conducted. The interviewees were explicitly asked about existing industrial housing systems and the market perspectives for 
industrial housing systems. This step guided the selection of the four housing systems to be researched in our multiple case-study.

The second phase consisted of the selection and interviewing of 17 professionals who have played a key role in the adoption and diffusion of W\&R in the Netherlands. In-depth interviews with these key actors served to develop an understanding of how $\mathrm{W} \& \mathrm{R}$ managed to remain competitive and successful for already more than 25 years. The focus in the interviews was on: (1) gaining insight into how the decision-making process of selecting and adopting novel housing systems takes place; (2) uncovering the unique characteristics of $\mathrm{W} \& \mathrm{R}$ as a rare example of an industrial housing system that has been able to sustain itself, and; (3) identifying the specific reasons for selecting $W \& R$ and rejecting alternative housing systems. In addition to these interviews, we also conducted in depth interviews with the key actors involved in the adoption and diffusion process of the Concrete Slab housing system, the Wooden Frame housing system and the Steel Frame housing system. The average duration of all the interviews was about 1.5 hours. The interview protocol was adapted to each interviewee's specific role in the decision-making network and the contextual setting. To avoid excluding important issues, the respondents were also asked to add any influencing factors that had not been addressed and which they thought to be relevant for the decision outcome to adopt. If possible and with the permission of the respondents, the interviews were recorded, and the recordings were used in transcribing the interviews. Further, interviewees were asked to provide documents or other written or electronic material to illustrate or complement their statements, and these were used as additional sources of data.

In the third phase, a content analysis of the interview reports was undertaken using ATLAS.ti. 6.2. In line with the procedure for content analysis recommended by Boeije [52], every document was 'open coded'. In the next step, through 'axial coding', the case study data was reorganized and reassembled. This was then used as input for 'theoretical coding', where relationships between data fragments were identified in order to explain the nature of adoption decision-making. Point of departure of this analysis was the close examination of how and why the housing system of interest was adopted. This revealed how clients select a housebuilder and which considerations are key to adoption.

During the fourth phase a cross-case comparison was conducted following Miles and Huberman's interactive model of data management and analysis [48, 49]. After coding the interview transcripts, data was displayed by constructing four separate in-depth case study narratives including a series of supporting figures and tables. The output of the four case studies were subject to cross-case analysis following the recommendations of Miles and Huberman [48] and Miles, Huberman and Saldana [49]. The cross-case analysis encompasses a variable-oriented approach where variables are compared across the four case studies. The case specific determinants are compared with each other to arrive at generic mechanisms. These generic mechanisms are constructed following several iterations of re-examining the case data and completing the cross-case table (Table 2).

In the fifth phase, the case study findings were processed and synthesized in a scientific report that was discussed with the W\&R Management Team and the former directors of the Concrete Slab, Wooden Frame and Steel Frame housing systems. The management team and directors confirmed the case study findings as an accurate description of the adoption and diffusion of their respective housing system. During the meeting with the W\&R Management Team, also the plans and prospects for the W\&R approach were discussed.

Finally, a workshop, annexed to a symposium, was organized in which the results of this study were presented. Over 60 people, all active in the housing development market and including most of the interviewees, attended. The debates were taped and then analysed following the same content analysis procedure as with the interview transcripts. 


\section{The stage-gate selection process}

The W\&R case study showed how the adoption of an industrial housing system is intrinsically linked to project procurement following a stage-gate selection process. During successive steps housebuilding firms and bids are evaluated and selected until one bid remains. In this section, we explain the successive steps in the stage-gate adoption decision-making process that are applied by clients when selecting their preferred builder for a housing project. This will also provide insight about essential criteria that suppliers of innovative housing systems in the Netherlands should meet to be considered as acceptable for social and commercial property developers in their role as investor and client.

There are three types of clients for W\&R houses: social housing associations; commercial investors; and the AM Property Development (AMPD), an in-house commercial property developer belonging to BAM. Of the 20,000 housing units constructed so far, about $50 \%$ result from in-house projects, $30 \%$ link to social housing projects and the remaining 20\% constitute commercial house building. Typically, the clients of $\mathrm{W} \& \mathrm{R}$ are involved in large-scale single-family housing projects, which define the low-end housing market and occasionally housing for the middle class sector in The Netherlands.

In the planning process to build houses on a specific parcel, social housing associations and commercial property developers, have to determine the number and type of houses to build. In this decision-making process, the developers have to comply with prescriptions laid down by the local municipality. For example, a municipal zoning plan may prescribe the dimensions of individual plots, or the type and number of houses and other buildings that may be built in a specific area. Thus, land availability and planning issues have a great effect on creating demand for housing systems like W\&R. In addition, planning decisions of social housing associations are guided by social housing policies of the Dutch government, i.e. the investment costs of the project need be recovered primarily by rent, for 2019 limited at $€ 720,42$ monthly.
To realize their building plans, housing associations and commercial property developers also have to select a house-building firm with whom to realize a project and whose housing system they will adopt. The selection and procurement of a house-building firm can best be characterized as a stage-gate process. The process starts with an invitation to one or several potential building companies to make an offer. Each stage ends by weighing and filtering the alternative propositions made by the various companies. This filtering process is organized in such a way that a property developer is eventually able to select the most attractive housing system and building company to realize the project. The interviews with professional clients undertaken as part of this study showed that adoptions occur through a three-stage selection process: contractor selection, price selection and selection based on added value to the project (Fig. 1).

Two procurement strategies, competitive tendering and negotiated contracts, are found dominant in the low-end housing market. The former is more accustomed during periods of economic downturn to benefit from lowest price guarantees. Best-value procurement based on selective procedures has gained importance although these tenders tend to be dominated by lowest price considerations. In practice, 'best value for money' bids have a disadvantage due to a lack of instruments to value other qualitative aspects of the bid. Note that, according to Dutch Law, social housing associations are not seen as public institutions and are therefore not obligated to organize a public competitive tender (as long as projects are limited to housing). As a result, housing associations also apply negotiated contracts by inviting one or several contractors. Despite the differences between various tendering strategies, it seems that clients take into account the same set of considerations to evaluate the bid of industrial housebuilders. Even in the case that only one house builder is invited, the bid is assessed by the same set of criteria in the order as can be found in the stage-gate process in which lowest cost consideration dominate. 


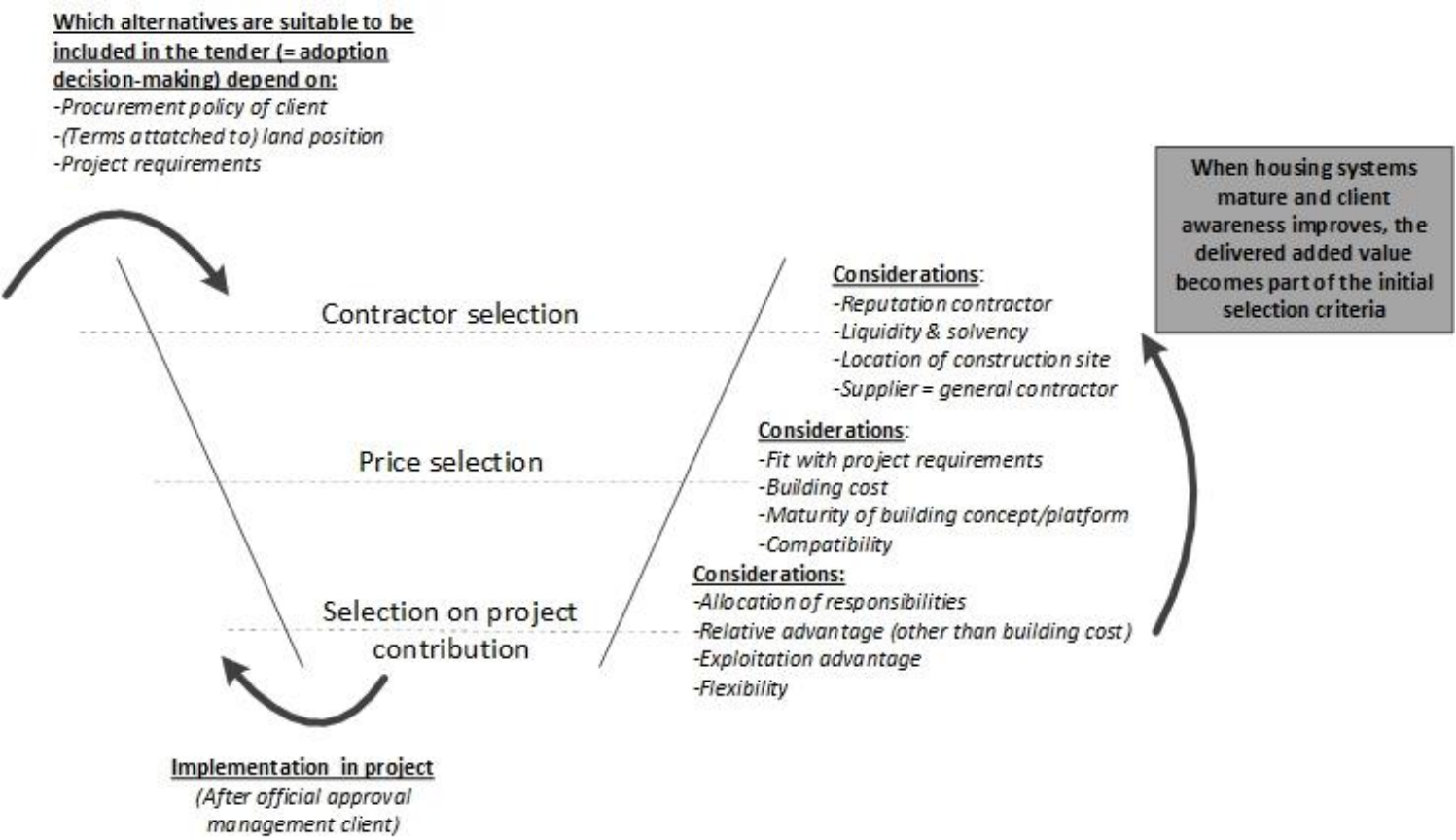

Fig. 1. The stage-gate decision making process for realizing housing projects in The Netherlands.

Table 1 provides an overview of the key considerations clients take into account when selecting a housebuilder. These considerations are confirmed by literature in the field of tender evaluation and contractor selection [53-56]. However, research in this field in particular still lacks empirical evidence about how contractor and tender selection criteria are evaluated by clients in case of deciding whether or not to adopt an innovation within a housebuilding project [42]. It becomes interesting to learn why W\&R has been and still is repeatedly selected in housebuilding projects, and why competitive alternatives failed to pass the stage-gate selection process.

\section{The W\&R housing system}

This section provides a detailed overview of the steps that were taken to adapt W\&R in the last 30 years to changing market developments and requirements. In the course of time, adoption criteria have been extended or further tightened in order to meet new requirements such as with respect to sustainability and energy performance. Subsequently we focus on the incremental innovation process steps that $\mathrm{W} \& \mathrm{R}$ followed to keep its attractiveness over time and which subsequently led to its continued adoption.

W\&R was introduced to the Dutch market in 1992. Since its introduction, over 20,000 W\&R houses have been built in the Netherlands across 300 different projects. Fig. 2 shows the yearly number of completed W\&R dwellings since 1992. One may observe a downward trend since 2008. This was due to the economic crisis (2007-2016) that emerged in the construction industry in the Netherlands, and which resulted in a severe annual decrease in housing production. However, since 2016, housing production increased again and a further increase is expected for the coming years.

In the last 25 years, the $\mathrm{W} \& \mathrm{R}$ housing system has proven to be a serious option for social housing associations and commercial property developers with low-cost and middle-class houses in their development plans. To accommodate the changing and tightening requirements demanded by these professional clients in the last few decades, the W\&R housing system underwent a series of adaptations. So far, three main phases of adaptation of W\&R can be identified: 
Table 1. Client considerations during the stage-gate decision-making process

\begin{tabular}{|c|c|c|}
\hline Stage of selection & $\mathrm{Co}$ & siderations by client \\
\hline \multirow{14}{*}{$\begin{array}{l}\text { 1.Contractor Selection } \\
\text { to Participate in the } \\
\text { Tendering Process }\end{array}$} & \multicolumn{2}{|r|}{ Considerations about selecting a house-building firm: } \\
\hline & \multirow[t]{7}{*}{ 1) } & $\begin{array}{l}\text { Which house-building firms are expected to be able to complete the } \\
\text { project successfully? }\end{array}$ \\
\hline & & $\begin{array}{l}\text { - Have acquired experience as main contractors - as well as } \\
\text { consultant - with respect to certain type of projects (i.e. new build } \\
\text { houses or retrofitting projects); }\end{array}$ \\
\hline & & $\begin{array}{l}\text { - Provide guarantees with respect to working conditions, quality and } \\
\text { environment c.q. sustainability; }\end{array}$ \\
\hline & & $\begin{array}{l}\text { - Have developed certain capabilities with respect to innovation and } \\
\text { supply chain integration; }\end{array}$ \\
\hline & & $\begin{array}{l}\text { - Have developed certain capabilities with respect to performance- } \\
\text { oriented project delivery; }\end{array}$ \\
\hline & & $\begin{array}{l}\text { - Have developed certain capabilities with respect to client } \\
\text { orientation; }\end{array}$ \\
\hline & & $\begin{array}{l}\text { - Are willing to share all information, i.e. to show transparency in } \\
\text { the way business is conducted; }\end{array}$ \\
\hline & 2) & $\begin{array}{l}\text { How trustworthy is the house building firm based on experiences in } \\
\text { previous projects? }\end{array}$ \\
\hline & 3) & $\begin{array}{l}\text { Are active within the region of the construction site; Which house- } \\
\text { building firms are active in proximity of the intended building site? }\end{array}$ \\
\hline & 4) & $\begin{array}{l}\text { Which of these house-building firms can be considered as viable, given } \\
\text { their liquidity and solvency positions? }\end{array}$ \\
\hline & 5) & $\begin{array}{l}\text { With respect to the proposed housing systems delivered by the house- } \\
\text { building firm: }\end{array}$ \\
\hline & & $\begin{array}{l}\text { - Is the housing system supplied by a house-building firm with a } \\
\text { reputation general contractor (in contrast to for example an } \\
\text { architect or component supplier)? }\end{array}$ \\
\hline & & - Is the housing systems considered sufficiently mature? \\
\hline
\end{tabular}

2.Contractor Selection on Price / Best Value for Money

\section{Considerations about the tender (quantitative):}

- Does the bid encompass all the functional project requirements?

- Is the bid financially transparent and complete?

- Does the bid fit within the project's budget?

- Which of the contractors has made the lowest bid?

\section{Additional Value against Lowest Price}

\section{Considerations about the tender (qualitative):}

- Which bid in terms of quality and service offers the best added value?
1) a process of product and process standardization;

2) the creation and implementation of a standardized range of housing solutions, so called "standardized variety", and; 3) the development and implementation of a differentiation strategy by offering housing solutions targeted at different market segments. Currently, W\&R seems to be entering its fourth phase, which can be characterized by the inclusion of service-oriented components. Fig. 3 provides an overview of the successive adaptations of the W\&R housing system since its early introduction in 1992 in the Dutch housing market. 


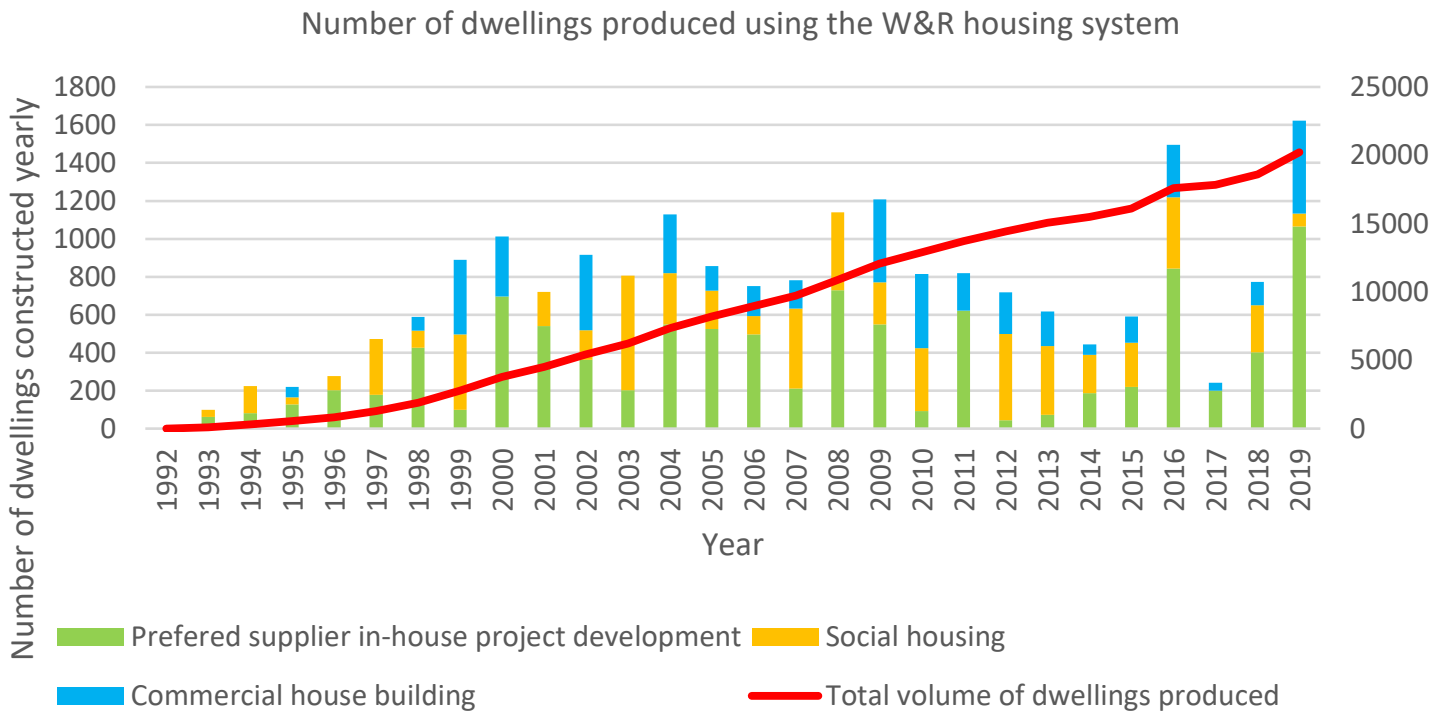

Fig. 2. The Number of constructed dwellings by the W\&R housing system since 1992

\#Note that a severe decline can be noticed in 2017 relative to 2016 (due to administrative issues - several projects started in 2016 and were completed in 2017 but were nevertheless administrated in 2016)

\subsection{The first stage: A process of product \& process standardization (1990-98)}

The first phase of the W\&R lifecycle encompassed the 'initial idea' of the system, the actual development of the system and initial market entry. The first phase anticipated and addressed the inefficiencies of housing delivery in the Netherlands. During the second half of the 20th century, the building of large series of dozens, or even hundreds, of similar dwellings, could characterize residential construction projects for single-family dwellings in the Netherlands. As such, construction could be characterized as mass production. The traditional project organization, with temporary coalitions of specialists, could support individual team-based learning but did not necessarily lead to increased organizational performance. To increase efficiency and learning, BAM decided to move on from this traditional project-based approach to single-family housing production by developing and implementing $\mathrm{W} \& \mathrm{R}$, which is based on the following four organizational principles.
- A Project-Independent Coalition with Preferred Subcontractors and Suppliers

The first organization principle that was implemented was a project-independent coalition with preferred subcontractors and suppliers for the construction of single-family dwellings. This resulted in a stable network of 42 partners. This coalition became one of the cornerstones of W\&R. Most of the original partners are still involved. BAM implemented long-term agreements with these partners, which resulted in (cost) efficient housebuilding and improved quality because of a substantial reduction of deficiencies, and reduced lead-time from start to finish of the project. Implementation of this organization principle made it possible to offer clients a fixed price and project planning and a guaranteed W\&R quality.

- A Standardized Development and Production Process

BAM implemented a standardized production process by applying reinforced concrete tunnel formwork to construct the concrete bare structure of the dwellings on-site to which the prefabricated subsystems are connected. 


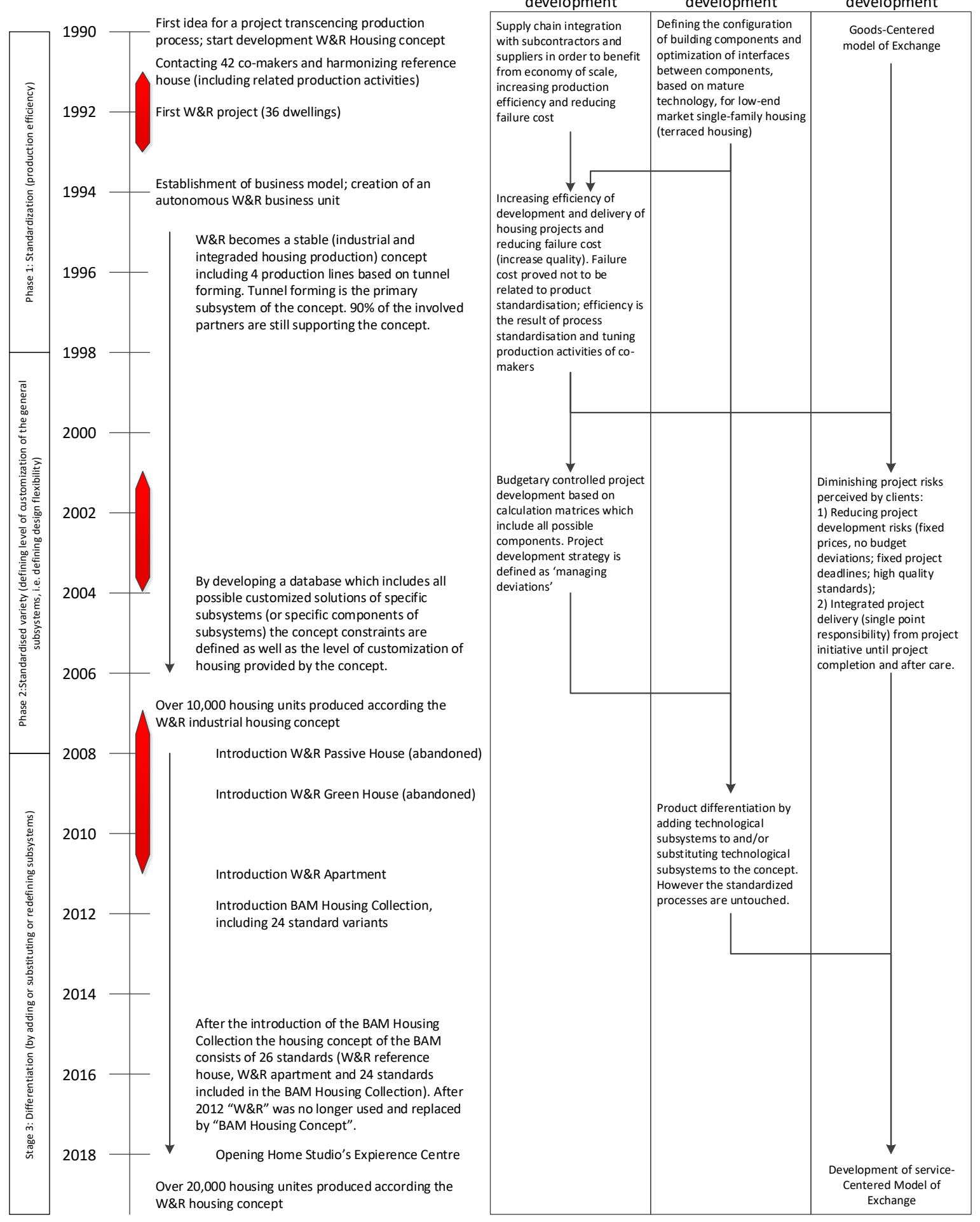

Fig. 3. Development of the W\&R housing system. The arrows reflect the cyclical nature of construction (periods of economic downturn) 
The production process was developed by BAM based on a reference house that represented the typical single-family dwellings in the Netherlands at that time. BAM, as the general contractor and system integrator, was and still is responsible for the on-site production of reinforced concrete tunnel formwork (forming concrete bays of separation walls and floors). All the other subsystems and related production activities are harmonized with the tunnel forming process. After production of the ground floor and first floor tunnels (and sometimes a second floor), the tunnel naves are closed with prefabricated façade elements. Next the roof, consisting of prefabricated gable-end elements and prefabricated roofing sheets, is put in place. As soon as the dwelling is wind- and waterproof, the finishing process is started, including bricklaying of the exterior walls, installation of the bathroom, kitchen and toilet, and additional finishing works such as plastering and tiling.

- A Stable Production Team in Terms of Composition and Members

The production teams move from site to site, avoiding changes in the team composition and in individual team members. That is, the same team members work together and become fully attuned to one another. This result in increased productivity and a substantial reduction in costs linked to failures or mistakes.

Over time, five production lines have been established, each producing about 200 dwellings yearly. During periods of economic downturn, the fifth production line stays unused. To ensure longterm production continuity, BAM focuses on running these four and maximum five production lines, even when market demand allows higher production numbers.

\section{- A Well-Considered Balance between Regionally and Centrally Directed Activities}

In order to be close to its potential clients, BAM's housing division operates from four regional independent offices spread across the Netherlands. These regional offices are responsible for the acquisition of new housing projects. The net benefits of a new housing project are allocated to the regional office concerned. Acquisition takes place by convincing potential professional clients of the competitive advantage of W\&R in terms of building quality and price, and the "single point of responsibility" approach that is followed by BAM. In this, BAM takes the overall responsibility for the whole realization process from design through to completion. Nevertheless, W\&R is centrally coordinated with respect to the procurement activities and the long-term agreements with building partners. The low price and short construction period that result from these applied organizational principles made $\mathrm{W} \& \mathrm{R}$ an attractive option for social and commercial property developers in the Netherlands.

\subsection{The second stage: Standardized variety (1998-2008)}

The second phase of the $W \& R$ lifecycle can be characterized as the creation of "standardized variety" by offering various standardized modulebased options. Around the turn of the century, consumers in the Netherlands were becoming dissatisfied with standardized houses, even though they were of a reliable quality. In response, BAM sought ways to accommodate and increase the influence of clients on the design of future housing development projects, but without increasing the price too much and losing the advantages of serial production. To produce the required variety efficiently, the $W \& R$ design was adapted to include modularity principles $[57,58]$. Standardized variety was created by offering different module-based options for facades and roofs, and for internal finishes, although the core design of the reference building remained untouched. These efforts resulted in a database of optional components that could be mixed and matched in customizing the building envelope. This set of options was codeveloped by BAM and its partners. This database approach, with limited standard options, enabled the consortium to work with fixed prices for each option. This approach enabled an increase in flexibility and variety in product design while maintaining product quality and production speed. 


\subsection{The third stage: Differentiation (since 2008)}

The third and current phase can be characterized by efforts to improve $W \& R$ in terms of its energy performance and in a decision to widen the scope of target clients. The economic recession that began in 2008 led to a stagnating Dutch housing market and intensified competition therefore. To distinguish itself from its main competitors, BAM decided to renew and further improve $W \& R$ by developing two sustainable variants: the W\&R Green House and the W\&R Passive House. During the same period, many competitors started to offer sustainable housing solutions and the competitive advantage of the W\&R Green House and the W\&R Passive House reduced. As a result, both variants were abandoned and instead several energy efficiency alternatives were developed. The alternatives can be selected as standardized module-based options.

Parallel to the development of the W\&R Green House and the W\&R Passive House 2 other pathways were explored to develop additional variants. The first pathway led to the development of the W\&R apartment building of which the first project was completed in 2011. Subsequently, in 2012 the BAM Housing Collection was introduced. The housing collection encompasses three popular architectural styles, which were identified in close collaboration with AM. For each style eight housing types were developed.

Technology advancement and labour shortage also forces the BAM to reconsider the production standards of the W\&R housing system. Offsite production technologies are considered to remain attractive in the Dutch housing market. In particular, prefabrication of the load bearing structure and prefab masonry are considered. At the same time, design, engineering and offsite production processes are automated by full application of Building Information Modelling (BIM).

\subsection{The fourth stage: Service orientation}

It is expected that, in the near future, property developers and occupants, will extend their requirements to include more service-based activities, and demand all-inclusive housing solutions. In particular, they will demand lifecyclebased services related to building services and maintenance. In addition, there is a growing demand from end-users for ready-to-move-into housing. New development projects are in progress at BAM to extend their portfolio to respond to demands for these types of services. Subsequently, in September 2018 BAM opened the Home Studio's Experience Centre. In contrast to current practices in the Dutch housing market, BAM attempts to address a growing demand for ready-tomove-into housing by providing services to install the complete infill of the dwelling. Home Studio's provides a real-time experience, which helps occupants to select and buy the total infill of their house.

Above we described the successive development stages of the W\&R housing system in order to maintain its attractiveness over time. This analysis revealed a close match between the characteristics of W\&R and the stage-gate adoption process applied in the housing sector. First of all, $\mathrm{W} \& \mathrm{R}$ adheres to the preconditions set by housing clients when selecting house-builders. The local market orientation and market responsiveness are also considered distinctive characteristics of W\&R. Since the completion of the first project in 1992, $\mathrm{W} \& \mathrm{R}$ gained a reputation of an efficient and affordable housing system. Based on a standardized housebuilding process and a stable project independent coalition of co-makers W\&R was able to develop and maintain a relative cost advantage in comparison with its competitors but could also often make the best value for money offer.

\section{Cross-case analysis: Deriving mechanisms of continued adoption}

In contrast to $\mathrm{W} \& \mathrm{R}$, many housing systems are not adopted beyond their demonstration phase. What differentiates the W\&R housing system from lesssuccessful housing systems in terms of continuous adoption? First, we will present three housing systems, which were not adopted at a large scale beyond their demonstration phase. These housing systems include Concrete Slab House; Wood Pod 
House and Steel Frame. Second, we analysed several case specific, causal mechanisms that affect continuous adoption (Table 2). Subsequently, we deduce the case-specific findings to five generic continued adoption mechanisms.

\subsection{Concrete Slab House}

The Concrete Slab House system was developed by a Dutch architectural design firm and further developed in collaboration with a contractor and several suppliers who delivered the core technologies. Since independent suppliers are making the different modules, the Concrete Slab House can be considered as an 'open system'. Fig. 4 shows the timeline with the key development steps and major (macro-economic) events hindering a continued adoption. The Concrete Slab House is based on a modular product architecture with standardized, interfaces connecting the specific modules. These industrial building modules include three subsystems: structural precast floor slabs, columns and exterior concrete sandwich wall elements. The functionalities of each subsystem are clearly defined and captured in standardized specifications and interfaces. Design and production flexibility is achieved by mixing and matching of the subsystems, and is based on standard steel couplings. As a result, and in contrast to traditional housing, building components can be fully disentangled. HVAC systems' pipes and ducts are not integrated in walls and floors but installed on top of the structural floor and are covered by a decoupled floor system in that the overall building can be adjusted in the future in accordance with changing needs.

The Concrete Slab House was adopted in 2009 in a project of a social housing corporation and 60 housing units were constructed. In addition, a couple of detached single-family dwellings were erected. Despite the advantages of the Concrete Slab House system (in 2010 the Concrete Slab House was awarded the sustainable building DUBO award), no further adoption by professional clients took place. Due to a lack of urgency and evidence, it appeared difficult to convince housing clients about the added value of the most important advantage of the Conrete Slab House, i.e. its flexibility to adapt the building against low costs. Initial building costs rather than time related life cycle considerations are still the dominant logic in awarding housing projects.

\subsection{Wood Pod House}

In contrast to the Concrete Slab House, which is based on 2D industrial building elements with fixed interfaces, the Wood Pod House has been based on industrial produced volumetric units. The basic structure of these volumetric units consists of a steel structure combined with timber frames. Although the ground floor initially also consisted of timber frames (to reduce weight) market demand required to redesign the floor by a steel frame concrete floor. The volumetric units were produced in a 'closed system' where the whole structure is prefabricated industrially in a single factory / production line.

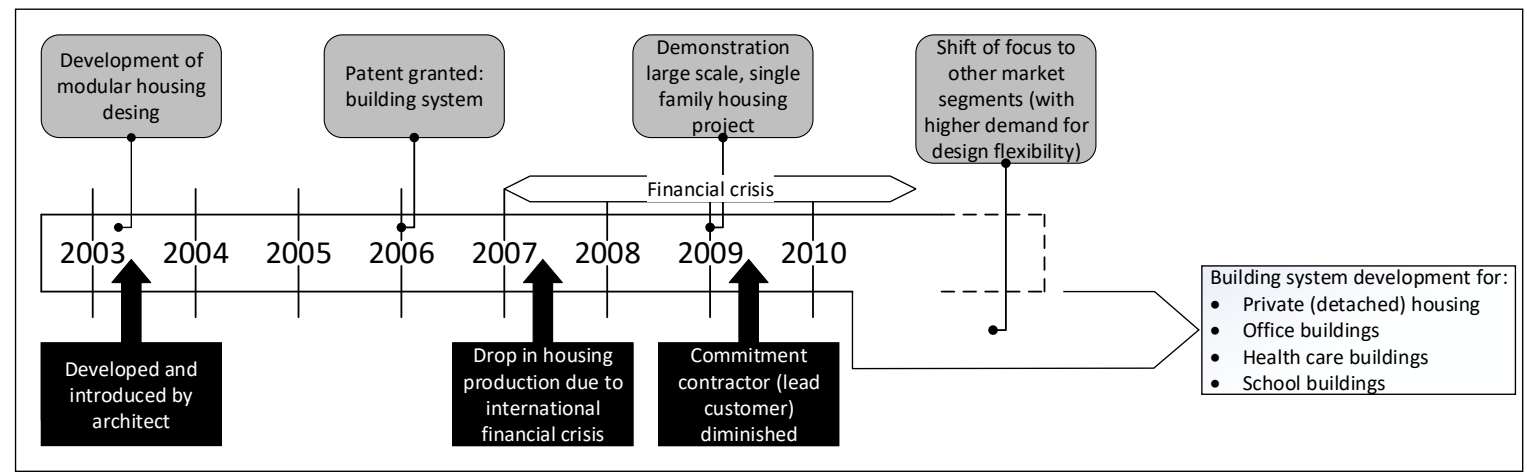

Fig. 4. Timeline Concrete Slab House system with key development steps and major (macro-economic) events hindering a continued adoption 
Besides the bare structure, also the infill modules, i.e. the bathroom and kitchen, are installed off-site. Standard sidings were used for the building exterior. A restriction related to volumetric units results from the maximum size, which can be transported by trucks as well as obstructions to reach the construction site like viaducts or narrow streets. The development of the Wood Pod House was the result of previous experiences with producing prefab holiday bungalows and subsequently the production of about 1,000 refugee dwellings in the period between 1999 and 2003 (during the Yugoslav wars 1991-2001). When the production of refugee housing stopped, the production facilities became obsolete and this stimulated the development of the Wood Pod House. Since 2004, about 500 single and multifamily houses were produced for the low-end market. This production ended in 2011 with the bankruptcy of the manufacturer. Fig. 5 shows the timeline with the key development steps and major (macro-economic) events hindering a continued adoption.

The Wood Pod House system was intitially developed for the production of housing solutions for a different market segment (holiday bugalows and refugee housing) and with deviating requirements. The volumetric units were responsible for high transportation costs ('we transport mostly air when moving volumetric units from factory to the building site').

To be able to compete in a cost-effective manner with traditional construction practices, the production line of the Wood Pod House system depended on large scale projects with a high level of replicability. It further turned out to be extremely difficult to anticipate fluctuations in demand. The economic crisis in particular resulted in a considerable decrease of large scale housing projects. In the same time, spatial planning policies in the Netherlands were changed towards a focus on the redevelopment of urban locations. This in contrast to urban expansion and house building on so-called green fields. As a result, the number of housing units per project deminished considerably which increased the cost per living unit for the Wood Pod House system. Thus, despite the maturity of the system and a proof of concept within a different market segment, it appeared not to be posible to realize a continued adoption for the Wood Pod House system.

\subsection{Steel Frame House}

Like the Concrete Slab House system, the Steel Frame House system is based upon an 'open system' approach where different modules are made by independent suppliers. A steel frame is used as bare structure supporting the wall and floor modules. The hybrid structural floor slaps are made of a concrete layer supported by steel ribs. The space between the steel ribs are used for the ducts and piping and are covered by a decoupled floor system which makes it possible to adjust the overall building in the (near) future.

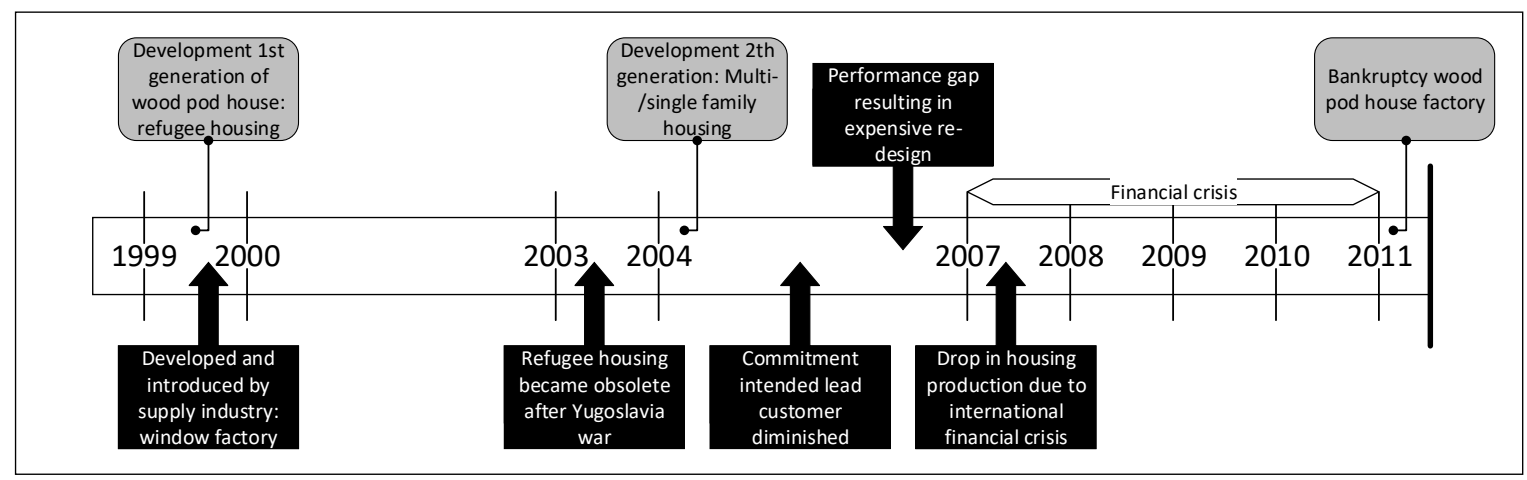

Fig. 5. Timeline Wood Pod House with key development steps and major (macro-economic) events hindering a continued adoption 
The building exterior walls consist of prefabricated sandwich wall elements while metal stud is used for the interior (separation) walls in order to create a flexible floor plan. Despite the leight weight of the building structure, laboratory tests showed that the building structure complies with building codes concerning fire protection, acoustics and structural integrity. The Steel Frame House (1994-1995) finds its roots in an university program to develop an 'innovative system of construction' which is based on the principles of Open Building [59-61]. Today the Steel Frame House system has been abandoned, it was never adopted beyond the demonstration project supported by the Industrial, Flexible and Demontable demonstration programme (19992006) of the Ministry of Economic Affairs. The pilot consisted of 36 single family dwellings which were constructed in 2000. Nevertheless the Slimline floor system, an essential subsystem of the Steel Frame House, is still available in the market and because of the successfull application of this floor system its reputation and uptake improves. Fig. 6 shows the timeline with the key development steps and the major (macro-economic) events hindering a continued adoption.

The relative advantage of the Steel Frame House comprises the flexibility and functionality of the dwellings which can be adjusted to accommodate future needs. The Steel Frame House system and in particular the innovative floor system (Slimline floor) earned recognition in the form of subsidies, an innovation award and a patent which was granted for the Slimline floor system. However, like the Concrete Slab House system, it appeared difficult to convince housing clients about the added value to pay extra for the created flexibility to easily adapt the building against low costs in the (near) future. Another reason for the resistance to adopt the Steel Frame House system in The Netherlands has been the difference between the traditional massive concrete floor of $800 \mathrm{~kg} / \mathrm{m} 2$ that is normally used in dwellings versus the choice for a hollow core floor system in the Steel Frame system. Although laboratoy tests revealed that the acoustic performance of both systems was comparable, the general acceptance of the new developed hollow core floor system caused resistance and skepticism. Finally, also the development of raw material prices had a negative effect on the continued adoption of the Steel Frame House system. Since its market introduction in the mid 1990s the price of construction steel increased rapidly and as a result the Steel Frame House system became too expensive in comparison with traditional solutions.

Despite its perceived relative advantages with respect to industrialization, flexibility and sustainability, one may argument that the Steel Frame House system was launched in a too early time and that it also deviated too radically from traditional construction practices that were used in those times. This explaines why a continued adoption appeared to be difficult for this system.

\subsection{Deriving mechanisms of continued adoption}

The generic continuous adoption mechanisms were developed iteratively, by comparing the mechanisms found across the four case studies, and re-examining each individual case. From this five mechanisms were identified which play a determining role in the continued adoption of W\&R: the housing system supplier needs to have a regional presence; needs to deliver operational excellence; comply with technology standards in the housing sector; needs to provide competitive added value, and; needs to be able to comply with changing market needs. Each mechanism ties together several adoption determinants as addressed in Table 2.

\section{- Contractor Characteristics}

In the first phase of contractor selection, the building competence of the contractor and their financial solvency and liquidity situation are important criteria. For innovators developing housing systems it is important to closely work together with their main suppliers (as co-developer or lead customer) while property developers only tend to invite house builders to submit a tender for their projects. 


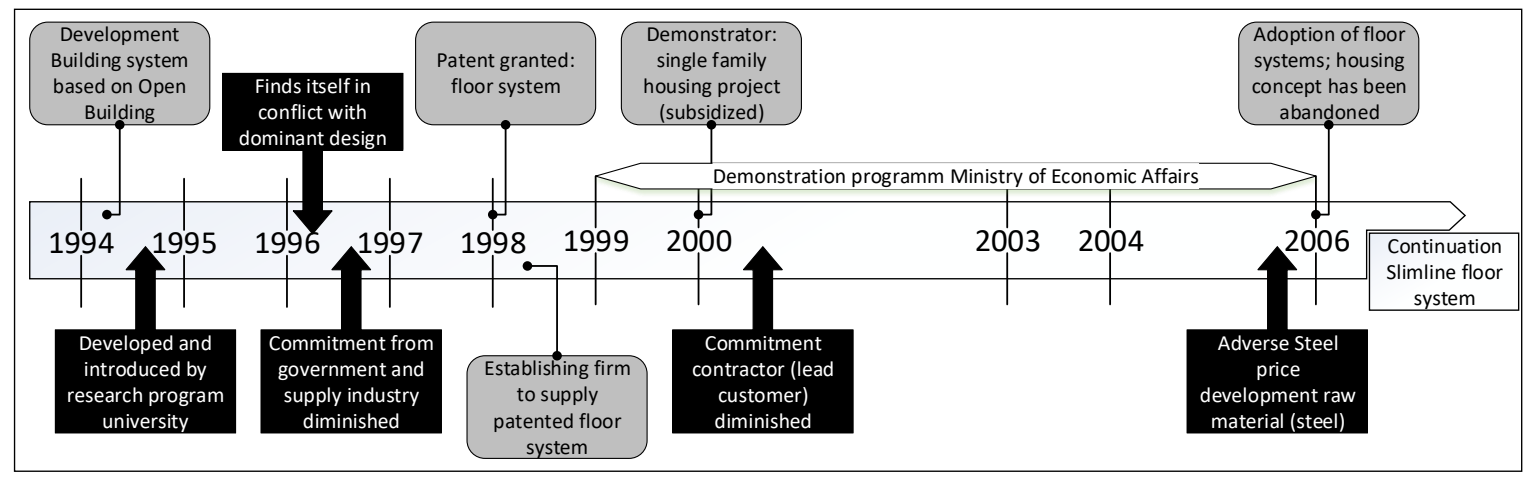

Fig. 6. Steel Frame House with key development steps and major (macro-economic) events hindering a continued adoption

Besides that, property developers, at least in the Netherlands, also consider the regional presence of the contractor, the availability of a single point of responsibility for the project, and the proposed housing system to have a proven maturity as important selection criteria. Within the W\&R case, the initial maturity of the housing system was demonstrated by the building of a reference house that reflected the then current best features of single-family dwellings constructed for social housing in the Netherlands. As explained earlier in this paper, BAM operates from four regional commercial business units that are responsible for the acquisition of new housing projects. Acquisition takes place by convincing potential clients of the relative competitive advantage of the W\&R system in terms of building quality and price, and highlighting the "single point of responsibility" approach that is followed by BAM. In this, BAM takes overall responsibility for the whole realization process from design to completion, thus meeting several of the selection criteria.

In contrast, the less successful housing systems did not meet one or several of these conditional adoption determinants. First, the demonstration projects completed did not provide proof of concept about the key relative advantages of the housing system. The demonstrators did not provide evidence about their capability to adapt the housing system to changing needs and neither they showed how the client could benefit from industrial building practices. Second, the suppliers of the less successful housing systems lacked some of the supplier characteristics of which regional presence is considered one of the most important.

Furthermore, while the continuity of production in the housing sector is hard to achieve and negatively affected by the cyclical nature of production, continued adoption could benefit from a proper project acquisition strategy. From the cross case analyses it was derived that becoming a preferred supplier of at least one client could sustain continued adoption.

Taken together, adopters take into account several supplier characteristics in order to manage the risks associated with the adoption of industrial housing systems. These supplier characteristics include: Regional presence; Involvement of the primary contractor (integrated project delivery); Liquidity and solvency of the firms involved; Previous experience (applying the innovation in other projects), and; Past performance (successful collaboration within previous projects).

\section{- Operational Excellence}

Treacy and Wiersema [62,63] outline potential business strategies that companies may successfully follow. They made a distinction between companies who excel in operations, in product leadership or who follow a customer intimacy strategy. Companies that pursue the Product leadership route offer a continuous stream of state-of-the-art products and services. The strategic Operational Excellence approach to the production and delivery of products and services aims to lead in terms of price and hassle-free service by making their operations lean and efficient. 
Table 2. Case study findings about identified determinants of continued adoption

\begin{tabular}{|c|c|c|c|c|c|}
\hline & & $\mathrm{W} \& \mathrm{R}$ & Concrete Slab House & Wooden Pod House & Steel frame House \\
\hline \multirow{2}{*}{ 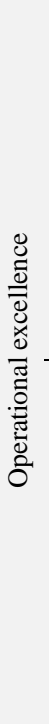 } & 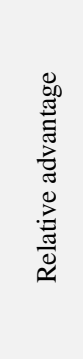 & $\begin{array}{l}\text { Relative advantage } \\
\text { encompasses several } \\
\text { determinants: investment } \\
\text { cost; improved building } \\
\text { quality; integrated housing } \\
\text { solution (single point } \\
\text { responsibility); design } \\
\text { flexibility; client (service } \\
\text { centric) involvement; } \\
\text { sustainable housing. }\end{array}$ & $\begin{array}{l}\text { Relative advantage } \\
\text { encompasses short project } \\
\text { lead-time and plug-and-play } \\
\text { installation on-site, flexibility } \\
\text { to alter the building to future } \\
\text { needs. }\end{array}$ & $\begin{array}{l}\text { Relative advantage } \\
\text { encompasses high production } \\
\text { efficiency and short project } \\
\text { lead time; high building } \\
\text { quality with minimum defects } \\
\text { as a result of a reduction of } \\
\text { on-site labour. }\end{array}$ & $\begin{array}{l}\text { Relative advantage } \\
\text { encompasses flexibility to } \\
\text { alter the building to future } \\
\text { needs; an industrialization } \\
\text { potential to solve labour } \\
\text { shortage problems and } \\
\text { improve the overall building } \\
\text { quality; potential to } \\
\text { disassemble the building at } \\
\text { the end of its life-cycle with } \\
\text { the potential to re-cycle. }\end{array}$ \\
\hline & 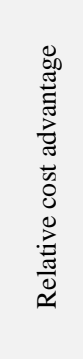 & $\begin{array}{l}\text { Competitive investment cost } \\
\text { per housing unit as a result of } \\
\text { applying a partnering concept } \\
\text { to overcome industry } \\
\text { fragmentation issues; stable } \\
\text { flow of projects; replicability } \\
\text { potential; low start-up cost; } \\
\text { applying building } \\
\text { components with the lowest } \\
\text { material prices; low } \\
\text { maintenance (life-cycle) cost }\end{array}$ & $\begin{array}{l}\text { Initial investment cost per } \\
\text { housing unit higher than } \\
\text { traditional house building } \\
\text { (although it needs to be taken } \\
\text { into account that only few } \\
\text { dwellings have been } \\
\text { constructed), effect on total } \\
\text { cost of ownership benefiting } \\
\text { from the flexible building } \\
\text { design yet unknown. }\end{array}$ & $\begin{array}{l}\text { Not competitive as a result } \\
\text { of: high start-up cost } \\
\text { production facility; negative } \\
\text { effect of a lack of continuity; } \\
\text { costly adjustments due to } \\
\text { project specific requirements, } \\
\text { immature solution; high } \\
\text { transport costs. }\end{array}$ & $\begin{array}{l}\text { Initial investment cost per } \\
\text { housing unit higher than } \\
\text { traditional house building } \\
\text { (although it needs to be taken } \\
\text { into account that only few } \\
\text { dwellings have been } \\
\text { constructed), effect on total } \\
\text { cost of ownership benefiting } \\
\text { from the flexible building } \\
\text { design yet unknown. }\end{array}$ \\
\hline 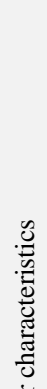 & 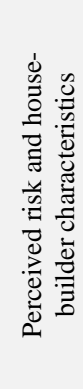 & $\begin{array}{l}\text { Several determinants } \\
\text { diminish the risk of negative } \\
\text { consequences: regional } \\
\text { presence; involvement } \\
\text { primary contractor, liquidity } \\
\text { and solvency of the firms } \\
\text { involved; previous experience } \\
\text { (applying the innovation in } \\
\text { other projects); past } \\
\text { performance (successful } \\
\text { collaboration within previous } \\
\text { projects). }\end{array}$ & $\begin{array}{l}\text { Risk of negative } \\
\text { consequences: lack of proof } \\
\text { of concept hinders adoption. }\end{array}$ & $\begin{array}{l}\text { Perceived risk: reflect the } \\
\text { immaturity of the industrial } \\
\text { housing system. Unclear for } \\
\text { clients whether the supplier } \\
\text { should be considered a } \\
\text { subcontractor, co-maker/key } \\
\text { supplier or contractor. Both } \\
\text { aspects hindered adoption. }\end{array}$ & $\begin{array}{l}\text { Risk of negative } \\
\text { consequences: lack of proof } \\
\text { of concept; lack of legitimacy } \\
\text { of the technological } \\
\text { innovation involved (floor } \\
\text { system). Both aspects } \\
\text { hindered adoption. }\end{array}$ \\
\hline
\end{tabular}

While the continuity of production in the housing sector is negatively affected by the cyclical nature of the sector, during periods of economic downturn a continued adoption could benefit from horizontal supply chain integration: becoming preferred supplier.

\section{A natural fit with traditional} house building practices: standardization was used to improve efficiency (cost advantage) and quality (substantial lower failure costs) and subsequently contributed to vertical supply chain integration. During this process, design rules and standards where developed.

\section{Acquiring projects}

The supplier was not able to Acquiring projects problematic: how to persuade become preferred supplier of problematic: how to persuade potential clients and convey the benefits of the housing system? a contractor or commercial housing developer (despite direct innovation investments system? of a commercial housing developer).

\section{Not a natural fit with} traditional house building practices: not able to get the innovation normalized and convey the benefits of the innovation to clients.

\begin{tabular}{|c|c|}
\hline $\begin{array}{l}\text { Not a natural fit with } \\
\text { traditional house building } \\
\text { practices: insufficient mature; } \\
\text { not able to get the innovation } \\
\text { normalized. }\end{array}$ & $\begin{array}{l}\text { Not a natural fit with } \\
\text { traditional house building } \\
\text { practices: considered too } \\
\text { radical when introduced; not } \\
\text { able to get the innovation } \\
\text { normalized. }\end{array}$ \\
\hline
\end{tabular}

Products' interfaces: the same Products' interfaces: well-known building technologies are applied in every project. universal connectors applied for the interfaces between building components.
Products' interfaces:

Products' interfaces: the same interfaces are fixed due to the but innovative building production line. technologies are applied in every project. 
Table 2. Cont'd

\begin{tabular}{|c|c|c|c|c|}
\hline 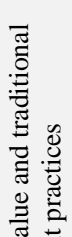 & $\begin{array}{l}\text { Traditional procurement } \\
\text { practices and prescriptive } \\
\text { project specifications, are } \\
\text { hindering adoption while } \\
\text { boundary conditions need to } \\
\text { be respected when applying } \\
\text { an industrial housing system. }\end{array}$ & $\begin{array}{l}\text { Idem, tradition construction } \\
\text { practices hindered adoption. }\end{array}$ & $\begin{array}{l}\text { Idem, tradition construction } \\
\text { practices hindered adoption. }\end{array}$ & $\begin{array}{l}\text { Idem, tradition construction } \\
\text { practices hindered adoption. }\end{array}$ \\
\hline 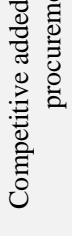 & $\begin{array}{l}\text { Number of completed } \\
\text { projects contributes to general } \\
\text { understanding of the added } \\
\text { value delivered to the project } \\
\text { (short project lead time; } \\
\text { consistent product quality and } \\
\text { reduced number of defects). }\end{array}$ & $\begin{array}{l}\text { System has higher initial costs } \\
1 \text { and the supplier was not able } \\
\text { to capitalize added value due } \\
\text { to a lack of instruments to } \\
\text { convey the (monetary) } \\
\text { benefits to the client. }\end{array}$ & $\begin{array}{l}\text { System has higher initial costs } \\
\text { and the supplier was not able } \\
\text { to capitalize added value due } \\
\text { to a lack of instruments to } \\
\text { convey the (monetary) } \\
\text { benefits to the client. }\end{array}$ & $\begin{array}{l}\text { System has higher initial costs } \\
\text { and the supplier was not able } \\
\text { to capitalize added value due } \\
\text { to a lack of instruments to } \\
\text { convey the (monetary) } \\
\text { benefits to the client. }\end{array}$ \\
\hline 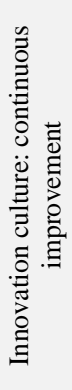 & $\begin{array}{l}\text { Development of a culture of } \\
\text { innovation including: 1) an } \\
\text { organizational structure } \\
\text { supportive to develop, test } \\
\text { and implement innovation; } \\
\text { 2) organizational culture with } \\
\text { common vision and } \\
\text { complementary goals; } \\
\text { 3) supply chain integration } \\
\text { and boundary spanning; } \\
\text { 4) learning infrastructure; } \\
\text { 5) commitment of clients. }\end{array}$ & $\begin{array}{l}\text { Close collaboration between } \\
\text { project stakeholders during } \\
\text { the demonstration project. } \\
\text { Not able to constitute a stable } \\
\text { long-term collaboration } \\
\text { between the involved } \\
\text { stakeholders which } \\
\text { jeopardized adoption beyond } \\
\text { the demonstration project. }\end{array}$ & No evidence found. & No evidence found. \\
\hline
\end{tabular}

Finally, the Customer Intimacy strategy is characterized by companies who continually tailor and shape products and services to fit one or a few customer niches. In order to be competitive, an enterprise needs to be at least competent in all three disciplines, but to be a market leader it is important to excel in just one discipline. Treacy and Wiersema further argue that an enterprise cannot excel in all three disciplines because the basic enterprise culture, structures, people, facilities, processes and business models that lead to excellence in any one discipline are incompatible with achieving excellence in the others.

By implementing these organizational principles, BAM was able to realize and maintain a cost leadership position in the housing industry in the Netherlands. Since price is an important criterion in the second phase of the stage-gate selection process, BAM's cost leadership position is often critical.

In contrast, the less successful housing systems were not able to master one of Treacy and Wiersema's business strategies and in particular turned out not to be competitive with respect to (initial building) cost. The less successful systems were hindered by several economic inertia including high investment cost in industrialised production facilities, high transport cost and, increasing raw material prices. In addition, the less successful industrial housing systems were not able to create continuity and scale in housing production. W\&R benefitted from its close collaboration with AMPD, a project development firm, being part of the Royal BAM Group. By consolidating a continued stream of housing projects, BAM was able to keep the production cost per housing unit low.

\section{- Natural fit with existing technology standards in the housing industry}

Nelson and Winter [64] defined a technological regime as 'the shared cognitive believe among technicians about feasible technologies' (p57). The empirical literature on technological regimes argues that firms within an industry behave in correlated ways because they share sources of information and technology and perceive similar opportunities for innovation. Firms in the same industry are also likely to have similar users that 
provide ideas and demand for innovation [65]. In the nineties the definition of a technological regime was refined by Van den Ende and Kemp [66] as: 'the complex of scientific knowledge, engineering practices, production process technologies, product characteristics, user practise, skills and procedures, and institutions and infrastructures that make up the totality of a technology' (p835). This extension was made because of the complexity of interactions between different actors such as users, policy makers, societal groups, suppliers and scientists in a technological regime. With respect to the potential adoption of new technologies, Rip and Kemp [67] pointed earlier to the difficulty to replace existing adopted technologies. Implementation, adoption, use, and domestication of technology create and maintain social and technical linkages that are hard to undo. This makes it very difficult for new entrants to replace a dominant technological standard or to change current construction practices and realize a continued adoption beyond the demonstration phase of a specific project.

The W\&R housing system applies mature construction technologies and BAM was able to innovate the construction process based on production line principles by working closely together with co-makers they already knew from previous projects. It turned out that the $\mathrm{W} \& \mathrm{R}$ housing system did not radically diverted from the traditional, technological regime of housing delivery in the Netherlands. In contrast, the less successful systems conflicted with the dominant technological standards in the housing sector. For instance, the Steel Frame House encompasses an innovative floor system, which separates the structural floor from the infill floor. As a result, the ducts and pipes included in the hollow core floor system can be adjusted during the building's life cycle. However, traditionally massive concrete floors are used in The Netherlands for decades because of their building-acoustic and fire-resistant properties. Despite laboratory tests proofing that the hollow core floor system meets the same performance criteria, the hollow core floor system was and still is questioned by the industry.

\section{- Competitive added value}

In the last stage of the selection process, property developers compare the remaining options in terms of their expected quality and any additional functionalities that are offered relative to the bid price. Aspects such as variety, flexibility, sustainability of materials, energy use and maintenance costs during the expected lifetime of the housing are potential additional criteria that may be used to compare the competitive biddings. Above all, as was learned from the $\mathrm{W} \& \mathrm{R}$ case study, upfront guarantees about investment cost and short project lead-time are considered to provide decisive added value to clients since it reduces potential project risks.

Next, in response to customer expectations, BAM has created, in the last decade, a variety of standardized (service) modules or options that can be selected. This has made it possible to increase the influence of clients on the design of housing solutions, while still maintaining an attractive price offering. In addition, a major effort was made to improve the W\&R housing system in terms of energy performance. To further prolong its competitive position, the company is working now on developing additional customer centric services.

Since the Concrete Slab House system, the Wood Pod House system and the Steel Frame House system did not survive the competition in the market, it will be difficult if not impossible to determine the competitive added value of these three specific housing systems.

- Ability of the builder to keep pace to changing market requirements

Over time, several adjustments were introduced in the W\&R housing system because of changing market requirements. These changing market requirements included the improvement of the sustainability of the housing system and providing additional services. In order to address changing market requirements, subsequently develop, and implement innovative solutions, BAM had to develop certain organizational capabilities. An extensive body of literature is available about the management of innovation by organizations in the construction sector (e.g. Bossink [36], Blayse and 
Manley [68], Gambatese and Hallowell [69], Gambatese and Hallowell [70], Gann and Salter [71], Reichstein, Salter and Gann [72], Reichstein, Salter and Gann [73]). From this body of literature, we were able to deduce five organizational design principles that may be considered important to support a continued adoption:

1. The involvement of a principal contractor as system integrator is key to innovation, managing 'ideas into good currency' [74]. This requires the development and alignment of competences in the regulatory framework, capabilities to incorporate client needs into the housing system, and skills to integrate technologies from the co-makers into the system as a whole. The case study has clarified the role of BAM as a system integrator. Innovations are developed, tested and implemented in close collaboration with a project-independent coalition of preferred subcontractors and suppliers.

2. An open, accepting and positive organizational climate and culture, is found to be conductive to innovation $[68,70]$. In the W\&R case study, the 'compatibility between organizations' was particularly mentioned as a characteristic aspect of innovation management process for the W\&R housing system. Firms appeared to share a common vision, had complementary goals, and were willing to share resources, knowledge, technical capacity and competencies to develop and implement new developments.

3. Supply chain integration and boundary spanning initiatives to co-innovate across the boundaries within and across organizations contribute to keep pace with changing market requirements and to maintain a competitive advantage over alternatives [36, 71]. With respect to the $\mathrm{W} \& \mathrm{R}$ housing system, these boundary spanning initiatives not only resulted into a stable network of collaborating partners and production teams, but also into close network ties with clients and architects.

4. Close network ties facilitate the required sharing of knowledge and information to develop and implement innovations to address changing market requirements $[68,71,74]$. In the W\&R case, the intense project-independent cooperation between co-makers created an innovation infrastructure that contributed to the development of learning and feedback loops. A stable project portfolio contributes to the development of certain organizational resources, in particular technological and integrative competences. These competences are required to develop and implement innovation.

A stable project portfolio will also reduce the risk of not recovering the initial development cost of innovations [68, 70, 71, 74]. In the past decades, the W\&R housing system organization has built up a reputation and past performance to acquire new projects.

\section{Discussion and conclusion}

This multiple case study is among the first to study the mechanisms which affect a continued adoption of industrial housing systems across housing projects in the Netherlands. Our multiple case study was guided by two research questions: 1) what differentiates the W\&R housing system from housing systems, which did not experience a continued adoption and, 2) which mechanisms contribute to a continued adoption over time and across housing projects?

Regarding the first research question, a key feature which differentiates $W \& R$ from the three other cases is its coherent organization and management of the successive stages in a housebuilding process. To really benefit from the potential that industrial housing systems have to offer, a well-coordinated planning and control is needed that integrates the interrelated processes of design, manufacturing, (on-site) assembly and other related processes such as procurement, sales and marketing [75-78]. The multiple case study showed that BAM, if compared with its less successful competitors, excels in the way how it organizes and manages the housebuilding value chain. Since the market introduction of the W\&R system, BAM has been able to integrate both the 
up- and downstream value chain. Downstream they built a stable network of partners with whom they collaboratively construct houses in large scale housing projects. Upstream BAM closely collaborate with architects and designers to offer design variety to housing clients. Moreover, in many projects they are involved as a consultant to support property development in order to maximise the potential of the $W \& R$ housing system, in particularly in projects developed by AM Property Development which is a subsidiary of the BAM holding.

The three less successful case studies showed that poorly controlled housing systems in terms of design, (pre-)fabrication and site assembly processes increase inefficiency and cost due to nonvalue-adding activities which in turn harm the potential benefits to be gained from industrialisation. The less successful housing systems in particular showcased partial and superficial supply chain integration.. Thus, supply chain integration is elementary to maximise the potential of industrial housing systems and as such key to continued adoption. Controlling the successive stages of the housebuilding process provides major possibilities for continued adoption, as it enables more autonomous development to improve efficiency and competitiveness in line with changing market conditions $[75,76]$.

This study has revealed the importance of maintaining a cost leadership position in the market and to keep pace with changing market requirements by further improving and developing the existing housing system. The W\&R housing system has evolved from a focus that was primarily on standardization, to standardized variety, to differentiation, and now towards the inclusion of a service orientation.

Regarding the second research question, we were able to deduce that the continued adoption of an industrial housing system in The Netherlands depends on: A regional presence of the system provider; the provision of excellent low-cost housing solutions; A natural fit with existing technology standards in the housing sector; The offering of competitive additional functionalities and quality in addition to the low cost focus and; The flexibility of the organization to keep pace with changing market and society needs and requirements such as with respect to circularity, energy efficiency and low maintenance and life cycle costs.

Finally, we identified several limitations and directions for future research. Although the findings are based on an extensive longitudinal case study and three complementary case studies, to generalize the findings, additional empirical data is needed. To this end future research may focus on testing in a large-scale study the identified mechanisms that affect a continued adoption of industrial housing systems. A second limitation is that one market, namely large scale housing projects in the affordable (low-cost) housing market in The Netherlands has been studied. Future studies could extend the research to other market segments and to housing projects in other countries and use crossnational data to account for differences in institutional structure. Third, this article studied the role of professional housing clients in the procurement of housing systems in particular the low-end market. Future research could extend the study about the role that clients play in the process of a continued adoption of new developed building systems. This could help building developers to overcome the impediments they face in dealing with clients as a buyer of building solutions. Addressing the future research opportunities described above would be an important contribution, from an academic, managerial and a policy point of view. This research has contributed by offering a useful foundation for expanding the investigation about continued adoption in largescale studies and to other sectors. This will broaden our knowledge about the possibilities to realize continued adoption in the construction industry.

\section{References}

[1] Banfill P, Peacock A (2007). Energy-efficient new housing-the UK reaches for sustainability. Building Research \& Information, 35, 426-436.

[2] Egan J. Rethinking Construction: the report of the Construction Task Force on the scope for 
improving quality and efficiency in UK construction. Transport and the Regions, London, 1998.

[3] Gann D (1196). Construction as a manufacturing process? Similarities and differences between industrialized housing and car production in Japan. Construction Management \& Economics, 14, 437450.

[4] Ozaki R (2003). Customer-focused approaches to innovation in housebuilding, Construction Management and Economics, 21, 557-564.

[5] Van Hal A. Beyond the demonstration project: the diffusion of environmental innovations in housing. Delft University of Technology, Uitgeverij Æneas BV, Delft, 2000.

[6] Femenias P. Demonstration projects for sustainable building: towards a strategy for sustainable development in the building sector based on Swedish and Dutch experience. Chalmers University of Technology, Göteborg, 2004.

[7] ECSO, Improving energy and resource efficiency, in: E.C.S. Observatory (Ed.) Analytical Report, European Union, Brussels, 2018.

[8] ECSO, Improving the human capital basis, in: E.C.S. Observatory (Ed.), European Commission, Brussels, 2017.

[9] ECSO, Stimulating favourable investment conditions, in: E.C.S. Observatory (Ed.), European Commission, Brussels, 2018.

[10] Ross R, Cartwright P, Novakovic O. A Guide to Modern Methods of Construction. Bre press, 2006.

[11] Hartley A, Blagden A. Current Practices and Future Potential in Modern Methods of Construction. Banbury, UK, 2007.

[12] Taylor MD (2010). A definition and valuation of the UK offsite construction sector. Construction Management and Economics, 28, 885-896.

[13] NHBC F. Modern Methods of Construction, Views from the Industry. IHS BRE Press, 2016.

[14] NAO. Using Modern Methods of Construction to Build Homes More Quickly and Efficiently. National Audit Office, London, UK, 2005.

[15] Zhang X, Skitmore M, Peng Y (2014). Exploring the challenges to industrialized residential building in China. Habitat International, 41, 176-184.

[16] Lessing J, Stehn L, Ekholm A. Industrialised housing: definition and categorization of the concept. Annual conference of the International Group for Lean Construction, 18-21 July 2005, Sydney, Australia.
[17] Gibb AG (2001). Standardization and preassembly-distinguishing myth from reality using case study research. Construction Management \& Economics, 19, 307-315.

[18] Thuesen C, Hvam L (2011). Efficient on-site construction: learning points from a German platform for housing. Construction Innovation, 11, 338-355.

[19] Finnimore B. Houses from The Factory: System Building and The Welfare State. Rivers Oram Pr., London, 1989.

[20] Vogler A. The House as a Product, IOS Press, 2016.

[21] Grimscheid G, Scheublin F. New Perspectives in Industrialisation in Construction. A State-of-theArt Report, 2010.

[22] Blismas N, Wakefield R, Hauser B (2010). Concrete prefabricated housing via advances in systems technologies: Development of a technology roadmap. Engineering, Construction and Architectural Management, 17, 99-110.

[23] Kamar KA, Alshawi M, Hamid ZA, Nawi MN, Haron AT, Abdullah MR. Industrialized building system (IBS): revisiting the issues on definition, classification and the degree of industrialization. 2nd Construction Industry Research Achievement International Conference, 2009, Kuala Lumpur.

[24] Hamid Z, Kamar KAM, Zain M, Ghani K, Rahim AHA (2008). Industrialized building system (IBS) in Malaysia: the current state and R\&D initiatives. Malaysian Construction Research Journal (MCRJ), 2, 1-13.

[25] Arif M, Davidson CH (2009). The challenge of organizational design for manufactured construction. Construction Innovation, 9, 42-57.

[26] Lind H. Industrialized house building in Sweden: a stress test approach for understanding success and failure. 6th Nordic Conference on Construction Economics and Organisation, 2011.

[27] Thillart CCAMvd, Customised Industrialisation in the residential sector-mass customisation modelling as a tool for benchmarking, variation and selection. Delft University of Technology, 2004.

[28] Goodier C, Gibb A (2007). Future opportunities for offsite in the UK. Construction Management and Economics, 25, 585-595.

[29] Pan W, Gibb AG, Dainty AR (2007). Perspectives of UK housebuilders on the use of offsite modern methods of construction. Construction Management and Economics, 25, 183-194. 
[30] Pan W, Gibb AG, Dainty AR (2008). Leading UK housebuilders' utilization of offsite construction methods. Building Research \& Information, 36, 5667.

[31] Rahman MM (2013). Barriers of implementing modern methods of construction. Journal of Management in Engineering, 30, 69-77.

[32] Egmond C, Jonkers R, Kok G (2006). A strategy and protocol to increase diffusion of energy related innovations into the mainstream of housing associations. Energy Policy, 34, 4042-4049.

[33] Matinaro V, Liu Y (2015). Virtual design and construction: innovation process and diffusion in Finnish construction business. International Journal of Innovation and Learning, 18, 133-150.

[34] Naney D, Goser C, Azambuja M. Accelerating the adoption of lean thinking in the construction industry. 20th International Group for Lean Construction, 2012.

[35] Brown J, Hendry C (2009). Public demonstration projects and field trials: Accelerating commercialisation of sustainable technology in solar photovoltaics. Energy Policy, 37, 2560-2573.

[36] Bossink BAG (20049. Managing drivers of innovation in construction networks. Journal of Construction Engineering and Management, 130, 337-345.

[37] Bossink BA (2015). Demonstration projects for diffusion of clean technological innovation: a review. Clean Technologies and Environmental Policy, 17, 1409-1427.

[38] Bossink BA (2017). Demonstrating sustainable energy: a review-based model of sustainable energy demonstration projects. Renewable and Sustainable Energy Reviews, 77, 1349-1362.

[39] Heiskanen E, Nissilä H, Lovio R (2015). Demonstration buildings as protected spaces for clean energy solutions-the case of solar building integration in Finland. Journal of Cleaner Production, 109, 347-356.

[40] Haavik T, Mlecnik E, Rødsjø A (2012). From demonstration projects to volume market of sustainable construction. Energy Procedia, 30, 1411-1421.

[41] Murphy ME, Perera S, Heaney G (2015). Innovation management model: a tool for sustained implementation of product innovation into construction projects. Construction Management and Economics, 33, 209-232.

[42] Murphy M, Heaney G, Perera S (2011). A methodology for evaluating construction innovation constraints through project stakeholder competencies and FMEA. Construction Innovation, 11, 416-440.

[43] Keegan A, Turner JR (20029. The management of innovation in project-based firms. Long Range Planning, 35, 367-388.

[44] Dainty AR, Cheng M-I, Moore DR (20059. Competency-based model for predicting construction project managers' performance. Journal of Management in Engineering, 21, 2-9.

[45] Mustonen-Ollila E, Lyytinen K (2003). Why organizations adopt information system process innovations: a longitudinal study using Diffusion of Innovation theory. Information Systems Journal, 13, 275-297.

[46] Mitropoulos P, Tatum CB (2000). Forces driving adoption of new information technologies. Journal of Construction Engineering and Management, 126, 340-348.

[47] Yin RK. Case Study Research: Design and Methods, SAGE Publications, 2003.

[48] Miles MB, Huberman AM. Qualitative Data Analysis: An Expanded Sourcebook. Sage Publications, Incorporated, 1994.

[49] Miles MB, Huberman AM, Saldaña J. Qualitative Data Analysis: A Methods Sourcebook. Thousand Oaks, CA: Sage, 2014.

[50] George AL, Bennet A. Case Studies and Theory Development in the Social Sciences, MIT Press, Cambridge, Massachusetts, 2005.

[51] Gerring J. Case Study Research: Principles and Practices, Cambridge University Press, New York, 2007.

[52] Boeije H. Analysis in qualitative research, SAGE Publications Ltd, London, 2010.

[53] Holt G (2010). Contractor selection innovation: examination of two decades' published research. Construction Innovation, 10, 304-328.

[54] Yang JB, Wang H-H, Wang W-C, Ma S-M (2016). Using data envelopment analysis to support bestvalue contractor selection. Journal of Civil Engineering and Management, 22, 199-209.

[55] Watt D, Kayis B, Willey K (20099. Identifying key factors in the evaluation of tenders for projects and services. International Journal of Project Management, 27, 250-260.

[56] Cheaitou A, Larbi R, Al Housani B (2018). Decision making framework for tender evaluation and contractor selection in public organizations with risk considerations. Socio-Economic Planning Sciences, 68, 100620. 
[57] Veenstra VS, Halman JIM, Voordijk JT (2006). A methodology for developing product platforms in the specific setting of the housebuilding industry, Research in Engineering Design, 17, 157-173.

[58] Hofman E, Modular and architectural innovation in loosely coupled networks: matching customer requirements, product architecture, and supplier networks. University of Twente, Enschede, 2010.

[59] Kendall STJ. Residential Open Building. E \& FN Spon, 2000.

[60] Habraken NJ, Teicher J, Supports: An Alternative to Mass Housing. Routledge Revivals, 1972.

[61] Bosma KH, Van D, Vos M. Housing for the Millions. John Habraken and the SAR (19602000), NAI Publishers, Rotterdam, 2000.

[62] Treacy M, Wiersema F (1993). Customer intimacy and other value disciplines. Harvard Business Review, 71, 84-84.

[63] Treacy M, Wiersema F (1995). How market leaders keep their edge. Fortune, 131, 52-57.

[64] Nelson RR, Winter SG (1977). In search of useful theory of innovation. Research Policy, 6, 36-76.

[65] Leiponen A, Drejer I (2007). What exactly are technological regimes? Intra-industry heterogeneity in the organization of innovation activities. Research Policy, 36, 1221-1238.

[66] Van den Ende J, Kemp R (1999). Technological transformations in history: how the computer regime grew out of existing computing regimes. Research Policy, 28, 833-851.

[67] Rip A, Kemp R. Technological Change. Battelle Press, 1998.

[68] Blayse AM, Manley K (2004). Key influences on construction innovation. Construction Innovation: Information, Process, Management, 4, 143-154.

[69] Gambatese J, Hallowell M (2011). Factors that influence the development and diffusion of technical innovations in the construction industry. Construction Management and Economics, 29, 507-517.

[70] Gambatese J, Hallowell M (2011). Enabling and measuring innovation in the construction industry. Construction Management and Economics, 29, 553-567.

[71] Gann D, Salter A (2000). Innovation in projectbased, service-enhanced firms: the construction of complex products and systems. Research Policy, 29, 955-972.

[72] Reichstein T, Salter A, Gann D 820059. Last among equals: a comparison of innovation in construction, services and manufacturing in the
UK. Construction Management and Economics, 23, 631-644.

[73] Reichstein T, Salter A, Gann D (2008). Break on through: Sources and determinants of product and process innovation among UK construction firms. Industry and Innovation, 15, 601-625.

[74] Winch G (1998). Zephyrs of creative destruction: understanding the management of innovation in construction. Building Research \& Information, 26, 268-279.

[75] Lindgren J, Emmitt S (20179. Diffusion of a systemic innovation: a longitudinal case study of a Swedish multi-storey timber housebuilding system. Construction Innovation, 17, 25-44.

[76] Kamar KAM, Hamid ZA (2011). Supply chain strategy for contractor in adopting industrialized building system (IBS). Australian Journal of Basic and Applied Sciences, 5, 2552-2557.

[77] Lessing J, Stehn L, Ekholm A (2015). Industrialised house-building-development and conceptual orientation of the field. Construction Innovation, 15, 378-399.

[78] Vrijhoef R, Koskela L (2000). The four roles of supply chain management in construction. European Journal of Purchasing \& Supply Management, 6, 169-178. 